\title{
HOUSING TENURE SECURITY IN RTLH PROGRAM OF SURAKARTA INDONESIA- HOW CAN IT CONTRIBUTE TO ACHIEVE SUSTAINABLE DEVELOPMENT GOALS OF POST-2015 AGENDA?
}

\author{
Winny Astuti \\ Center for Information and Regional Development Universitas Sebelas \\ Maret, Indonesia \\ Urban and Regional Planning Department Universitas Sebeals Maret \\ Indonesia \\ E-mail: winnyast64@gmail.com
}

\begin{abstract}
Abstract. This paper evaluates the Program of Substandard Housing (RTLH) Renovation proposed for the agenda of "Surakarta Informal Settlements Clearance 2015" for solving the problem of improving the quality of 6612 substandard houses. This research took a case study approach in the smallscaled area of poor settlements in the prone area along the riverbank of the Bengawan Solo River, namely Kelurahan Ketelan. How could this outcome contribute to achieve Sustainable Development Goals (SDGs) in terms of providing housing security to establish an inclusive, safe, resilient and sustainable city and human settlement as stated by SDGs? The case study research was conducted by multiple methods of qualitative and quantitative analysis. The results showed that the program had the highest contribution on the improvement of sanitation, in terms of the use of septic tank (change value of 0.5750) and the use of toilet (0.203) as one of the priorities of SDGs. However, there was only a small contribution in increasing access to land tenure security (0.002). It was surprising that the improvement of housing construction itself was not high. This program involved the collaboration among state-civilsociety-community and other development parties and increased channeling of assistance for settlements' sustainability and poverty reduction
\end{abstract}

Keywords: Post-2015 Agenda, sustainable human settlements, housing tenure security, inclusive development 


\section{INTRODUCTION}

The need for sustainable human settlements development had been understood by the governments of the third world since Habitat conference I in Vancouver 1976 as consequences of rapid urbanization processes. Habitat conference II had stressed two great agendas of "adequate shelter for all" and "sustainable human settlements development in an urbanizing world". Due to the more complicated problems of urban life in the provision of basic services, Habitat conference III promoted a new model of urban development that integrated all facets of sustainable development to promote equity, welfare and shared prosperity (UN Habitat, 2015). The Millennium Development Goals (MDGs), which were established in 2000 to address the achievement of 8 goals in 2015 had progressively achieved some goals of reducing the number of people living in extreme poverty by more than half, from 1.9 billion in 1990 to 836 million in 2015, since 2000. Additionally, the percentage of population using improved drinking water had been increased from $76 \%$ in 2000 to $91 \%$ in 2015 (MDGs report, 2015). However, some arguments stated that the MDGs had been mostly top down and was mostly discussed on political grounds regarding technical issues, risk management schemes, where millions of people were left behind and unequal development resulted in some parts of areas (MDGs report, 2015).

Meanwhile the MDGs had some obstacles. The Post-2015 Development Agenda gave serious attention to urban areas and the role of the local government. The Post-2015 Agenda was proposed for establishing more inclusive development, mobilizing stakeholders and addressing vulnerable people. The Post-2015 Agenda with 17 Goals was then proposed, as Sustainable Development Goals (SDGs) to mobilize stakeholders, promote integrated, city level approaches and accelerate progress towards sustainable development, including the end of extreme poverty (Satterthwaite, 2003). The Post-2015 Agenda's proposed SDGs were therefore addressed for more sustainable living, where urban areas faced more extreme poverty, environmental degradation of the living conditions of one billion informal settlements inhabitant and low productivity of urban living over the next three decades (Revi, 2013).

Inclusive development was integrated into the SDGs especially in a relational perspective, where the target was not only focused on assisting marginalized populations, but also on the relationship among various stakeholders in addressing poverty, and leading to beneficial effects for all (Gupta, 2015). The association with Community Based Development, where the development, actively involved beneficiaries in their design and management, led to mechanisms for channeling development assistance, allowed the communities to participate in the development process and direct control over project decision as well as management of financial support and investment; it integrated all facets of sustainable development and global community mobilization (The World Bank, 2003; Obermayr and Astuti, 2015).

Surakarta, a medium-sized city in Indonesia has been developing a community-based approach program, namely the RTLH Program, to solve a high 
poverty rate and targeted Surakarta Slum Clearance in 2015. This research evaluated the RTLH program implementation in the small area of Kelurahan Ketelan as a pilot project of the housing poverty alleviation program in 2006. This paper tried to evaluate how the RTLH Program contributed to the achievement of Sustainable Development Goals in terms of providing housing security for establishing an inclusive, safe, resilient and sustainable city and human settlement as stated by SDGs?

\section{Human Settlement Problems in an Urbanizing World, and the Emergence of Sustainable Development Goals (SDGs)}

The paradigm of Housing Policy has been shifted from structural adjustment programs to poverty alleviation, with indicators that can be measured from: 1) security of tenure; 2) structural quality/durability of dwellings; 3) Access to safe water; and 4) access to sanitation facilities. This accords with Moser's (1996) arguments that Key Indicators for Poverty Alleviation on the Housing Sector are: Access to Housing, which targeted the goals of 1) adequate housing for all in terms of housing production; 2) adequate housing quality and space related to floor area per person and a permanent dwelling unit; 3) secure housing tenure, in regard to increasing the percentage of the total housing stock in the urban area which is in accordance with current regulations. Sustainable Development Goals of a Post 2015 Agenda targeted (Revi, 2013): 1) reducing extreme urban poverty, expanding job opportunities and productivity, especially in slums and informal settlements, 2) ensuring the universal access to a secure and affordable built environment and urban services, such as housing, water, sanitation, waste management, low carbon energy transportation and communication, 3) ensuring safe and adequate air and water quality for all, reduction of the greenhouse effect, efficient land and resource use, and climate and disaster resilience. Out of 17 goals, goal $11^{\text {th }}$ is especially targeted making cities and human settlements inclusive, safe, resilient and sustainable (Output Document of the Open Working Group on Sustainable Development Goals, 2014). The post-2015 goals are therefore proposed to "Empower Inclusive, Productive, and Resilient Cities". This is supported by Target 11.2, that by 2030, all cities provide access to safe, affordable, accessible and sustainable transport systems for all, and target 11.7 stated that by 2030, all cities are to provide universal access to safe, inclusive and accessible, green and public spaces, in particular for women and children, older persons and persons with disabilities (http://un.org.au)

\section{Sustainable Development Goals, Inclusive Development, and the Contributions of the RTLH Program.}

Rualdo Menegat (2002) saw sustainable development as integrated urban environmental management, which is concerned with: citizen participation; public environmental management programs; comprehensive knowledge of Porto Alegre's natural and built environments; and environmental education. Related to the housing sector, the argument by CESCR, 1991 in Revi 2002, stated that sustainable cities are the right of adequate housing, including several core elements: legal tenure security, 
including protection against forced evictions; availability of services; affordability, in which housing costs should be affordable for occupants; accessibility, which considers the needs of disadvantaged and marginalized groups; habitability, providing physical safety, adequate space, protection from the elements; location, in relation to employment opportunities, health care, schools, childcare centers; and cultural adequacy. While Chance (2009) argued about the concept of sustainable residential communities, which stressed energy efficiency consumption, water consumption, efficient energy design, sustainable transportation usage; also waste and recycling. Sustainability in the settlement's development planning should be able to connect with community demands in the wider context of urban development. The concept of sustainability and its role in housing policy should be brought into a broader concept to embrace economic and social dimensions as well as environmental concerns (Bramley, 2009).

The RTLH Program gave housing renovation grants to the beneficiaries of poor people living in substandard housing, which were intended for secure housing for creating more sustainable living, combating poverty, environmenta degradation of living conditions, all as stated in the Post 2015 Agenda. This program integrates an urban poverty alleviation policy with Slum Upgrading by Government intervention in the improvement of housing construction, while at the same time improving the environment condition, improving the provision of infrastructure and public services, transportation accessibility as well as economic condition, through the collaboration of various stakeholders. The RTLH program was operated by community involvement, the formulation of Community-based Organization, namely POKJA (working Group) and widening collaboration and partnership with non-governmental organizations (NGOs) and other grassroots organizations (GROs). It conformed to the concept stated by Das, 2015, where in a Slum Upgrading Program, Community-based organizations (CBOs), non-governmental organizations (NGOs) and other grassroots organizations (GROs) emerged as key players in the new urban development paradigm. Slum upgrading (SU) emerged as a comprehensive planning tool for providing sufficient infrastructure and services in urban poor settlements through the interventions of the government physically, socially, economically, environmentally, and legally (UN-Habitat, 2003); also enabled communities to undertake key tasks, such as designing and budgeting, with the authority and flexibility role of CBOs (Krishna, 2003). Local governments were recommended to promote community participation activities early in the planning cycle of identification, planning/design, financing, implementation/construction, monitoring and evaluation, and maintenance Plummer (2000).

\section{THEORY / RESEARCH METHODS}

The research was a case study utilizing multiple methods of qualitative and quantitative analysis on the implementation of RTLH Program in Ketelan Surakarta, as it benefitted 44 households. The research was conducted in several stages:

1. Evaluation of RTLH Program implementation in Surakarta was a part of the Surakarta Slum Clearance Agenda 2015. This stage was conducted through a interview survey of the parties involved as follows: BAPPEDA (Bureau of 
Planning and Development); BAPERMAS PP PA and KB (Bureau of Community Empowerment. Woman Empowerment and Family Planning); DTRK (Government Unit of Spatial Planning); BPN (National Agrarian Bureau) and POKJA (Working Group) of RTLH. Indeed, regulatory and policy frameworks had also been explored in order to shape the formal context.

2. Field survey and a questionnaire survey of the beneficiaries of the RTLH program were carried out with 31 out of 44 households. Aspects of the analysis used in the research were concerned with indicators of sustainable settlements development as follows: Access to housing and land tenure security; Access to social services and infrastructure; Affordability of urban and social services; Environmental management and Economic development.

3. The analysis was conducted through $\mathrm{T}$ test analysis, which determined the change in conditions before and after implementation of the program related to the variables listed in Table 1. If P-Value $<\mathbf{0 . 0 5}$, therefore Ho was rejected, which meant that there was a significant difference between before and after implementation of RTLH Program, and where P-value $>0.05$, therefore Ho was accepted which meant that there was no significant difference between before and after implementation of the RTLH Program. This was continued by analysis of explanations and further exploration of the contribution of each aspect of sustainable development, as relating to a post-2015 agenda directly of indirectly.

Table 1. Variables of Contribution of Housing Intervention Program Aspects to the Component of SDGs on Cities and Human Settlement Development Agenda

\section{Contribution of Housing Intervention \\ Program to the achievement of SDGs on \\ Cities and Human Settlement \\ Development Agenda}

Access to Housing and Land Tenure

Security

Access to Services and Social Infrastructure

Affordability of Urban and Social Services

Environmental Management and Economic Development

\section{Indicators}

\section{(n)}

1. Housing affordability

2. Adequate housing for all

3. Adequate housing quality and space

4. Secure Housing Tenure

5. Provide equal access to credit

6. Provide equal access to land

Access to water supply sufficiency

Access to improved sanitation

Quality and access to garbage management

1. Affordability for water supply services

2. Affordability for Electricity usage services

3. Affordability for Garbage management services

4. Affordability for health services

5. Affordability for education services

6. Affordability for transportation services

Promote effective and environmentally sound transportation systems 
Table 1. Variables of Contribution of Housing Intervention Program Aspects to the Component of SDGs on Cities and Human Settlement Development Agenda (continued)

\title{
Contribution of Housing Intervention Indicators \\ Program to the achievement of SDGs on \\ Cities and Human Settlement \\ Development Agenda
}

\begin{abstract}
Strengthen small and micro enterprises, particularly those developed by women Encourage public-private sector partnership and stimulate productive employment
\end{abstract}

Source :Analysis Astuti, adopted from Moser, 1996; Un Habitat 2004 and other sources

\section{RESULTS AND DISCUSSION}

\section{The RTLH Program of Surakarta City and Its Contributions for sustainable Development Goals as a Post-2015 Agenda}

Surakarta is a municipal city located in the core city of SUBOSUKA region, Central Java Indonesia. This is surrounded by the Regency of Boyolali, Sukoharjo and Karanganyar, with the area of $44.04 \mathrm{~km}$ dominated by developed areas with the population of about 600,000 people. The level of poverty has reached $22 \%$ covering 125,600 urban poor people (TKPKD, 2011). The number of households located in inadequate houses and infrastructure was found to be 36,933 in the five districts of Banjarsari (12,136 hh); Laweyan (5,204 hh); Serengan (3,398 hh); PasarKliwon $(6,202 \mathrm{hh})$ and Jebres $(9,993 \mathrm{hh})$ (BPS, 2011). Out of these numbers of households, 1571 of them live in squatter settlements on government land and illegal land, such as railway and riverbank areas in Surakarta City (Figure 1 and 2).

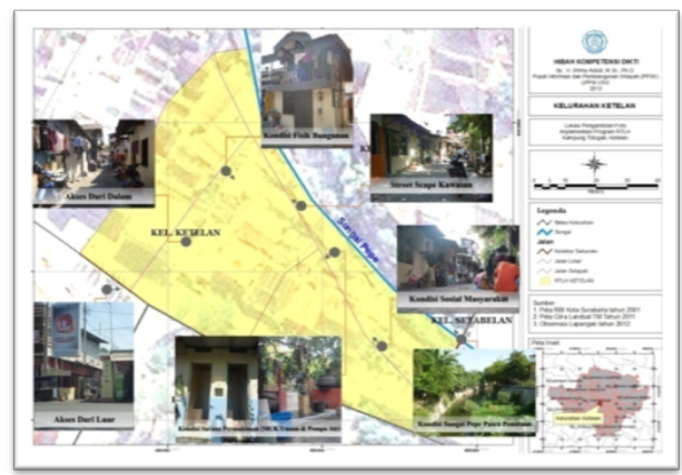

Figure 1. Study Area of RTLH Ketelan in Surakarta Sources: Fieldwork, 2012-2013

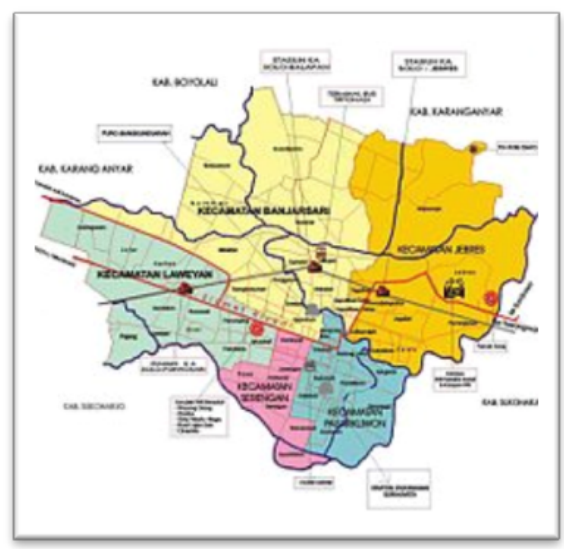

Figure 2. Map of Surakarta Sources: Fieldwork, 2012-2013 
The Program of RTLH Housing Improvement was established in order to overcome the problems of decreasing housing and environmental quality in Surakarta, by grants for renovation and rehabilitation of substandard houses from Rp 2 to 5 million for each house. In 2006, it was reported that the number of substandard houses was 6612 RTLH in 5 kecamatan (districts). It was claimed that until 2011, the Government of Surakarta had realized 4,986 houses to be renovated and 1,250 houses in 2012. (Table 2)

Table 2. Realization of Grants for RTLH Housing Improvement Program in Surakarta

\begin{tabular}{|c|c|c|c|c|c|c|c|c|c|}
\hline \multirow{2}{*}{$\begin{array}{l}\text { District/Ke } \\
\text { camatan }\end{array}$} & \multirow{2}{*}{$\begin{array}{l}\text { Total } \\
\text { RTL } \\
\text { H } \\
2006\end{array}$} & \multicolumn{7}{|c|}{ Beneficiaries : Number of RTLH Housing units Improved } & \multirow[t]{2}{*}{2012} \\
\hline & & 2006 & 2007 & 2008 & 2009 & 2010 & 2011 & Total & \\
\hline Laweyan & 819 & 16 & 128 & 188 & 186 & 111 & 27 & 656 & 107 \\
\hline Serengan & 530 & 14 & 82 & 24 & 157 & 210 & 0 & 487 & 107 \\
\hline $\begin{array}{l}\text { Pasar } \\
\text { Kliwon }\end{array}$ & 2115 & 85 & 322 & 533 & 448 & 60 & 30 & 1478 & 411 \\
\hline Jebres & 1447 & 56 & 221 & 325 & 323 & 103 & 107 & 1135 & 212 \\
\hline Banjarsari & 1701 & 54 & 247 & 391 & 386 & 66 & 86 & 1230 & 413 \\
\hline TOTAL & 6,612 & 225 & 1,000 & 1,461 & 1,500 & 550 & 250 & 4,986 & 1,250 \\
\hline
\end{tabular}

This program needed community organization as a prerequisite of the implementation. In the pre-planning stage, the program initiation had been by the community itself, facilitated by a key person in the community. The government responded to the initiative after 2 years. Then a working group of the community, called POKJA (kelompok Kerja), was formed based on Perwali 2007. The urban planning department of Surakarta therefore started to design site plans, and BPN legalized the land tenure ownership. In the implementation stage, the community did the housing improvement gradually, starting with the land tenure certificate as the pre-requirement for housing improvement. The implementation of the program was done together among departments of the local government of Surakarta, led by BAPPERMAS. In this case, BAPPEDA acted to facilitate all organizations involved. There was an effort to access credit facilitation by BLU Griya Layak Huni and LKM CU Kapidarmo, but it had not been done successfully. In the post program implementation, inter-organizational networks were included: BAPPEDA, BAPERMAS, DTRK, BPN, PDAM, PNPM, BLU Griya Layak Huni. Interorganizational networks after the program finished, were continued by PNPM and BPN. The mechanism of the RTLH Program implementation was in line with the Post-2015 Agenda, which targeted empowering inclusion for the city's sustainability, which was socially inclusive, economically productive and environmentally sustainable. This program involved all facets of development, 
including the government units, non-Government Organization as well as the private sector.

\section{Housing Tenure Security in RTLH Program and the Component of SDGs in Cities and Human Settlement Development Agenda}

The contributions of the housing sector toward the component of SDGs in the cities and human settlement development agenda were determined from access to housing and shelter; access to services and social infrastructure; affordability of urban and social services; environmental management; and economic development

\section{Access to Housing and Land Tenure Security}

The research found that the housing conditions were improved, because the specific objective of the RTLH Program was increasing access to good quality of house by distribution of grants of $\mathrm{Rp} 2$ to 5 million for renovation of substandard housings for each of targeted household. Other contributions of the program were full access for the beneficiaries to fulfill their need to adequate housing, including area width and physical condition (roof, wall and floor conditions). Even though in the beginning targets only focused on housing and environment improvement, there were some multiplier effects of improving land tenure legalization. Apart from that, the RTLH program also lead for improving urban infrastructure and services, especially access to water (PDAM) and sanitation (public sanitation), improving management of the planned environment and increasing economy for local microenterprises by opening wider access to credit, using the land certificate as collateral. This program created networking among the government units in providing urban infrastructure, tenure certification as well as social and economic development.

Table 3. Results of T-test Analysis of Housing Condition

\begin{tabular}{lccc}
\hline \multicolumn{1}{c}{ Aspects } & P-Value & Conclusions & Value of Change \\
\hline $\begin{array}{l}\text { Condition of roof } \\
\begin{array}{l}\text { Condition of wall } \\
\text { material }\end{array}\end{array}$ & 0,000 & Significantly different & 0.68750 \\
Condition of floor & 0,001 & Significantly different & 0.50000 \\
& & Significantly different & 0.93750 \\
\hline
\end{tabular}

Sources : Fieldworks Astuti, 2014

Land tenure security still continued to be one of the most suppressing problems of the urban poor. Tenure security improved access of the urban poor to credit, housing, infrastructure and services. Legal aspects discussed here were the method of acquisition, legalization of land and housing ownership status. As discussed before, one of the parts of the RTLH Program area was located in the flood-prone area of the riverbank, which was a restricted area for residential use. The program had revitalized some areas for the Greenbelt and gave secure tenure to the rest of the area. By the concept of the CBD, this program had enhanced the partnership of the National Agrarian Bureau in the local government to grant land 
titling of the area. Legalization of land tenure, as the pre-requirement condition before the housing improvement program ran, increased. After the program finished, $100 \%$ of beneficiaries had legal ownership of the land. Even though the program had legalized the land and housing tenure, Table 4 shows that the contribution of the program toward land tenure security improvement was low (0.02). The high contribution was in the way to obtain housing, because most of the beneficiaries obtained housing ownership from the government (0.14).

Table 4. Results of T-test Analysis of Tenure Security

\begin{tabular}{lccc}
\hline \multicolumn{1}{c}{ Aspects } & P-Value & Conclusions & $\begin{array}{c}\text { Value of } \\
\text { Change }\end{array}$ \\
\hline Way to obtain house & 0,014 & Significantly different & 0.344 \\
Housing ownership & 0,002 & Significantly different & 0.281 \\
\hline
\end{tabular}

Sources :Analysis Astuti, 2014

\section{Access to Services and Social Infrastructure}

The Major Regulation number 17-A /2009, stated in Act 7, the RTLH Program was targeted for increasing the condition of housing construction and environmental condition in terms of drainage system, local street, and lowering density. As the CBD program, the overall Indonesian National Program, in spite of encouraging local communities to participate in the planning process and providing financial support to the communities, the program had also allowed direct and transparent funding of poverty-alleviation activities, and enhanced partnership of central and local governments to best provide services based on demand. Because the "Kroyokan Program" was developed during the implementation of the program, the Department of Public Works (DPU) financially supported the provision of services

Table 5. Results of T-test Analysis of Access to Services and Infrastructure

\begin{tabular}{lccc}
\hline \multicolumn{1}{c}{ Aspects } & P-Value & Conclusions & $\begin{array}{c}\text { Value of } \\
\text { Change }\end{array}$ \\
\hline Water supply services & 0,103 & Not significantly different & 0.167 \\
The usage of toilet & 0,203 & Not significantly different & 0.208 \\
Condition of Septic Tank & 0,575 & Not significantly different & 0.042 \\
\hline \multicolumn{2}{c}{ Surces : Analysis, 2014 }
\end{tabular}

\section{Affordability of Urban Services}

Affordability of urban services was identified as including affordability of water services; electricity services; garbage management services; health services; education services and transportation services. From the questionnaire survey, it was found that there was a slightly increased payment for water supply services in the implementation of the program, though most of the urban service payments were not increased. 


\section{Environmental Management and Economic Development}

Environmental management of resources and hazards, improved economic efficiency, social equity and long-term sustainability of the area, environmental improvement, enhanced the development potential of the city, benefitted to the human health, and helped control environmental hazards (UN Habitat, 2001). The RTLH Program was not indicated for environment management, where the community-based organization, formulated during the implementation of the program does not have a longterm development plan for environmental management of the area. From the FGD, this program showed improved management of the planned environment and increasing economy for local microenterprises by opening wider access to credit, with the land usage certificate as collateral. However, the analysis showed that there were no improvements in economic development as the program had been implemented for less than 8 years.

\section{Analysis of Contribution of RTLH Program to the Component of SDGs on Cities and Human Settlement Development Agenda}

Contributions of RTLH Program to the components of SDGs were observed from the changed conditions before and after implementation of the program. The results of the T-test analysis showed that the RTLH program had only significantly contributed to infrastructure and public services; access to housing and secure tenure. Access to infrastructure focused here included water and sanitation, and also garbage management. After the program, the beneficiaries that had access to adequate, clean and healthy water supplied by PDAM increased. Figure 3 and Table 5 indicates that the RTLH Program had increased the condition of septic tanks (0.575), access to public toilets (0.203), access to water supply (0.103). As in the SDGs agenda, sanitation was among the important targets for cities and human settlements development. It was associated with target 11.7: By 2030, providing universal access to safe, inclusive and accessible, green and public spaces, in particular for women and children, and the disabled. Target 11.7 would contribute to the NCD target in SDG 3 (Ensuring healthy life) by providing places for people to be physically active (Daniel, 2015).

However, even though the RTLH program had legalized land and housing tenure, table 6 shows that the contribution of the program to the improvement of land tenure remained low. High contribution was in the way to obtain housing, because most of the beneficiaries obtained housing ownership from the government $(0,14)$. It was also found that the RTLH Program was initiated to only distribute housing construction grants. The improvement of physical housing conditions remained low in terms of improvement of roof condition, wall and floor material. Slight improvement was found in housing tenure condition $(0,002)$ and the way to own houses (0.014). Because the housing construction grants was fully subsidized by the program, it was found that condition of wall was permanently improved. This is indicated by the table 3, which describes that the beneficiaries mostly improved the condition of wall structure rather than the roof and floor conditions. This was partly because the housing renovation subsidy was very limited ( $\mathrm{Rp} 5$ million), 
which was only enough for wall condition improvement from bamboo or wood into brick material.

Table 6. Results of T-test Analysis of Contribution of Housing Intervention Program to the Component of SDGs on Cities and Human Settlement Development Agenda

\begin{tabular}{|c|c|c|c|c|}
\hline No. & Aspects & $P$ - Value & Conclusions & $\begin{array}{l}\text { Value of } \\
\text { Change }\end{array}$ \\
\hline 1 & $\begin{array}{ll}\text { Water } & \text { supply } \\
\text { services } & \end{array}$ & 0,103 & $\begin{array}{c}\text { Not significantly } \\
\text { different }\end{array}$ & 0.167 \\
\hline 2 & The usage of toilet & 0,203 & $\begin{array}{c}\text { Not significantly } \\
\text { different }\end{array}$ & 0.208 \\
\hline 3 & $\begin{array}{l}\text { Condition of Septic } \\
\text { Tank }\end{array}$ & 0,575 & $\begin{array}{c}\text { Not significantly } \\
\text { different }\end{array}$ & 0.042 \\
\hline 4 & Condition of roof & 0 & significantly different & 0.68750 \\
\hline 5 & $\begin{array}{l}\text { Condition of wall } \\
\text { material }\end{array}$ & 0,001 & significantly different & 0.50000 \\
\hline 6 & Condition of floor & 0 & significantly different & 0.93750 \\
\hline 7 & $\begin{array}{l}\text { Way to obtain } \\
\text { house }\end{array}$ & 0,014 & significantly different & 0.344 \\
\hline 8 & Housing ownership & 0,002 & significantly different & 0.281 \\
\hline
\end{tabular}

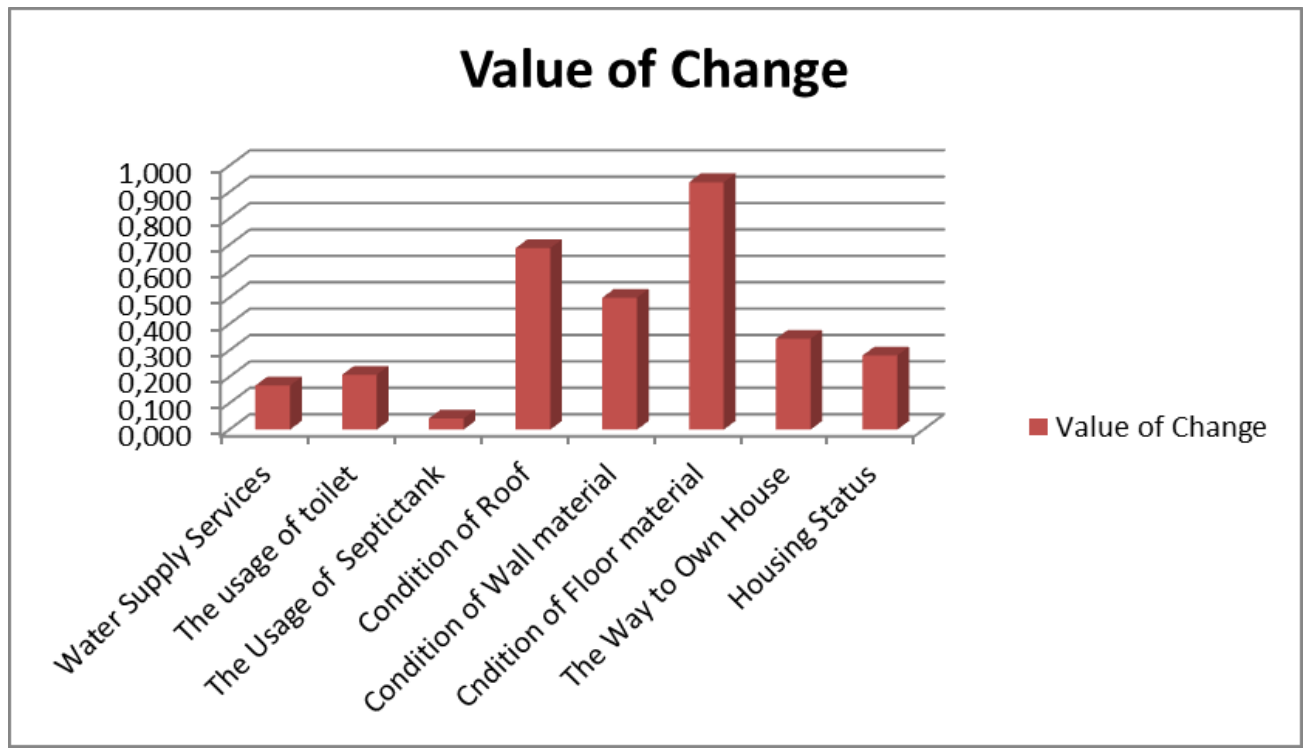

Figure 3. Results of T-test Analysis of Contribution of Housing Intervention Program to the Component of SDGs on Cities and Human Settlement Development Agenda

Sources : Analysis Astuti, 2014

\section{CONCLUSION}

The RTLH Program of Kelurahan Ketelan had created an effective collaborative planning of state- civil-society-community during the operation of the 
Program called "Kroyokan Program". The mechanism of the program was operated by a Community-based Organization called POKJA (Working Group), which had generated networking assistance during the program implementation with: BAPPEDA, BAPERMAS, DTRK BPN, PDAM, PNPM, BLU Griya Layak Huni and Inter-organizational networks after the program finished: PNPM, BPN. Therefore, it showed that even though the program only gave the government's subsidies for housing renovation and land purchasing, by collaborative planning of state- civil-society-community, it had generated an integrated program in achieving a post-agenda of sustainable human settlements development in alleviating housing poverty. The results of the program indicated improvement of housing and environment quality; improvement of urban landscape quality in terms of green open space availability, integrated quality improvement of infrastructure, legalization of land and reducing potential land conflict that might occur, and increased economic capacity.

The RTLH program in the local area of Kelurahan Ketelan had contributed to a sustainable human settlement program as a Post 2015 Agenda program in terms in increasing land tenure and housing ownership status, increasing housing condition and increasing infrastructure. The highest contributions were in the improvement of the condition of infrastructure, and condition of sanitation and water supply $(0.575$ and 0.103). It was in line with the agenda of SDGs for cities and sustainable development which placed sanitation and water supply sufficiency as the important issues which should be addressed. However the environmental management of the area, affordability of urban services, economic development and governance did not have any change or improvement.

\section{ACKNOWLEDGEMENT}

Directorate General of Higher Education (DIKTI) Indonesia for full financial support of this research; Rector and Head of LPPM, Universitas Sebelas Maret ; Chairman of PIPW LPPM UNS; Head of BAPPEDA; Head of SKPD Public Works. Chairman of BLU; Head of BPN and PDAM; Head of Kelurahan Ketelan and head of LPMK Ketelan, Head of POKJA RTLH Ketelan

\section{REFERENCES}

Astuti, W., et al. (2012)" Model of Empowerment for Slums Community as a Main element of Community-based Housing Development (CBHD)- Case Study in Tipes Village, Surakarta City, Indonesia", Proceeding of the National Seminar of Green Urban Housing Policy, $4{ }^{\text {th }}$ September 2012 Semarang, Planology UNDIP (1987)

Bapermas (2012) Report of Program RTLH Surakarta, 2012

Bappenas (2004) Laporan Perkembangan Pencapaian MDGs Indonesia, Februari 2004

BPS (2011) Data StatistikKota Surakarta 2011 
Bramley, G (2009). Urban Form and Social sustainability: the role of density and housing type. Journal of Environment and Planning B: Planning and Design, volume 36, pages 30-48 (2009)

Byrne, J, Wang, D.J ,Shen B and Li, X (1994) Sustainable Urban Development Strategies for China.Jurnal of environment and Urbanization, Vol 6, no.1, April 1994. Sage Publications

Chance, T (2009) Towards sustainable residential communities; the Beddington Zero Energy Development (BedZED) and beyond.Journal of Environment \&Urbanizat I O N Vol 21 No 2 October 2009. Sage Publication (2009)

Daniel, K (2015) Program Director, Livable Cities Program, HealthBridge Foundation of Canada, Ottawa. http://un.org.au/2015/06/12/sustainabledevelopment-goals-sdgs/2015

Das, A (2015) Autonomous but constrained: CBOs and urban upgrading in Indonesia A. Das / Cities 48 (2015) 8-20. Elsevier, publisher

Gupta, J, et all (2015) Sustainable Development Goals and Inclusive Development.POST 2015 / UNU -IAS.http://citiscope.org/habitatIII/2015

Mikkelsen, B (2001) Participatory research Methodology and Efforts for Empowerment- Books forPracticions, Jakarta, YayasanObor Indonesia (2001).

Moser, M.C (1996) Gatehouseand H. Garcia ..Urban Management And Poverty Reduction Urban Poverty Research Sourcebook Module Ii: Indicators Of Urban Poverty. UNDP/UNCHS (Habitat)/World Bank

Obermayr, C and Astuti W (2015) Paradigm shifts in the international housing debate and its local implications for Surakarta's approaches on housing the poor. Proceeding of 13 the International Asian Unbanization Conference, UGM, 2015

Pemerintah Kota Surakarta (2007) Perwali no 13/ 2007 regarding Mekanisme pemberian bantuan renovasi $R T L H$,

Revi, A (2015) The Urban Opportunity: Enabling Transformative and Sustainable Development. Background Paper for the High Level Panel of Eminent Persons on the Post-2015 Development Agenda. Prepared by the Sustainable Development Solutions Netwoks Thematic Group on Sustainable Cities(2013).

Rualdo, M (2002) Participatory democracy and sustainable development: integrated urban environmental management in Porto Alegre, Brazil. Journal ofEnvironment\&UrbanizationVol 14 No 2 October 2002, Sage Publication (2002)

Satterthwaite, D (2003) The Millenium Development Goals and Urban Poverty Reduction: great expectations and nonsense statistics, Jurnal of Environment and Urbanization Vol 15 no 2 October 2003

Sustainable Development Goals (SDGs)- Post 2015 Development Agenda .http://post2015.org/2015/...

TKPK (2001) A Big Job of Coordination Team of Local Poverty Alleviation. Article in Solopos 19 December 2011.

Turner, A (1987) Building Community. A third World Case Book- A summary of the habitat International Coalition Non-Governmental Organization's Project 
Astuti: HOUSING TENURE SECURITY IN RTLH PROGRAM OF SURAKARTA INDONESIA- HOW CAN IT CONTRIBUTE TO ACHIEVE SUSTAINABLE DEVELOPMENT GOALS OF POST-2015 AGENDA?

for the International Year of Shelter of the Homeless. In association with Habitat Forum Berlin (1987).

UN Habitat Program (2004) Urban Indicators Guidelines Monitoring the Habitat Agenda and the Millennium Development Goals

UN Habitat (2002) Cities without slums

Astuti, W (2012) Characteristics of Community-based Housing Development and its Contribution to Poverty Alleviation. Research of Competency, Directorate General of Higher education (DIKTI) 